\title{
Bilateral Pneumosinus Dilatans of the Maxillary Sinuses with Facial Pain
}

\author{
Kwang Ho Jin, Jeong Suk Choi, Young Hyun Kim and Myeong Sang Yu \\ Department of Otorhinolaryngology-Head and Neck Surgery, School of Medicine, Konkuk University, Chungju, Korea
}

\section{안면통증을 동반한 양측 상악동의 Pneumosinus Dilatans}

진광호 · 최정석 · 김영현 · 유명상

건국대학교 의학전문대학원 충주병원 이비인후과학교실

Received September 19, 2012

Revised January 23, 2013

Accepted January 31, 2013

Address for correspondence

Myeong Sang Yu, MD, PhD

Department of Otorhinolaryngology-

Head and Neck Surgery,

School of Medicine,

Konkuk University,

82 Gugwon-daero,

Chungju 380-704, Korea

Tel $+82-43-840-8280$

Fax +82-43-843-6165

E-mail hiyums@hanmail.net
Pneumosinus dilatans is a rare disease in which 1 or more paranasal sinuses are dilated without functional alteration. The frontal sinus is the most commonly affected site, with involvement of the maxillary sinus being rare. A 25-year-old man had complained of facial pain and headache of frontal area. These symptoms were aggravated after nose blowing. A computed tomographic scan showed a hyperaeration of both maxillary sinus and frontal sinus. We treated the condition by endoscopic sinus surgery (middle meatal antrostomy, both). Just after operation, facial pain and headache of frontal sinus have subsided. No recurrence was detected. In this article, the authors present surgical options for the treatment of pneumosinus dilatans of the maxillary sinus, including a review of the literature.

Korean J Otorhinolaryngol-Head Neck Surg 2013;56:233-6

Key Words Endoscopic surgery · Maxillary sinus · Pneumosinus dilatans.

\section{서 론}

Pneumosinus dilatans는 부비동의 일부 또는 전체가 비정 상적으로 확장된 상태로 부비동 내부에 점막병변이 없이 공기 로 채워져 있으며 골막의 비후가 없는 상태를 말한다.1) 전두동 에 가장 흔히 발생하며 사골동과 접형동의 순으로 나타나며 상악동의 경우는 드문 것으로 알려져 있다. ${ }^{2}$ 환자들의 얼굴모 양이 서서히 변형되거나 비폐색감을 호소하는 것이 일반적인 환자들의 증상이다. 드물게 안면부에 둔통을 호소하는 경우가 있지만 아직 통증의 발생 기전 및 치료 방향은 확립되어 있지 않다. ${ }^{3)}$ 저자들은 수년간 지속된 양측 안면통증을 주소로 내원 한 양측 상악동 pneumosinus dilatans 1예를 치험하여 문헌 고찰과 함께 보고하고자 한다.

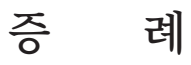

외상의 기왕력이 없는 25세 남자 환자로 8 9년 전부터 지속
되어 온 안면부 통증을 주소로 본원 이비인후과에 내원하였 다. 통증의 양상은 양측 상악부의 둔통과 충만감이었고, 아침 에 통증이 가장 심하고 최근 그 빈도가 잦아졌으며 코를 풀 때 더욱 악화되었다. 통증의 정도는 visual analogue scale(0: no pain 10: very severe pain)로 측정하였다. 길이 $10 \mathrm{~cm}$ 의 선 위 에 $1 \mathrm{~cm}$ 간격으로 표기를 하여 놓고, 0점부터 10점까지를 표기 한 후 환자에게 0 은 전혀 불편하지 않은 상태, 10 점은 너무 심 해 견딜 수 없는 상태라고 설명한 후 주관적인 통증의 정도를 선 위에 표시하도록 하였고 7점에 해당하였다. 환자는 두통으 로 생각하고 인근 신경과 및 내과에서 대증적인 치료를 받았 으며, 이비인후과에서도 부비동염으로 진단받고 항생제 치료 와 진통제 등으로 대증적인 치료를 받았다. 투약시에는 일시적 인 호전이 있었으나 재발과 호전이 반복되었다. 6년 전 스트레 스장애 진단하에 정신건강의학과에서 알프라졸람(alprazol $\mathrm{am)}$ 을 투여받았으며, 3년 전 군병원에서 비후성비염 진단하 하 비갑개 절제술을 시행받았으나 증상의 호전은 없었다. 1년 전부 터 본원 신경과에서 혼합성두통의증 및 삼차신경통의증으로 
카바마제핀과 비스테로이드성 소염진통제를 투여받았고, 본원 이비인후과에서 항생제 치료 및 진통제로 대증치료 하였으나 일시적 호전 후 다시 재발하는 양상으로 나타났다. 환자는 양 측 상악동 부위의 안면통과 간헐적인 수양성 비루로 재내원 하 였다. 비내시경 소견상 우측의 비중격 만곡증과 하비갑개 절제 술을 받은 상태 및 좁은 중비도가 관찰되었다(Fig. 1). 구강 및 안면부, 경부에는 특이 이상소견은 관찰되지 않았으나 외형상 상악동 및 전두동이 돌출된 양상으로 관찰되었다(Fig. 2). 부 비동 전산화단층촬영상 비정상적으로 팽창된 양측 상악동과 전두동을 관찰할 수 있었다. 상악동은 상방의 안와 하벽이 얇 아져 있고, 협골과 하방의 치조골까지 일부 함기화되어 있었으 나 골막의 결손이나 점막의 이상 소견은 보이지 않았다(Fig. 3). 혈액검사상 혈청 총면역 글로불린 $\mathrm{E}$ (정량)는 16.1 로 측정되었 으며, 항원특이적면역 글로불린E 검사에서도 알레르기를 시 사하는 소견은 나타나지 않았다.

흡기시 증가하는 통증의 양상과 부비동 전산화단층촬영 소
견으로 pneumosinus dilatans 추정 진단하에 부비동내시경 수술을 계획하였으며 환자가 외형적인 부분에 대한 불만족은 호소하지 않아 미용적인 수술은 계획하지 않았다. 부비동의 감 압 및 환기를 위하여 양측 경중비도상악동 개방술(middle meatal antrostomy)을 시행하였다. 수술중 상악동 개방 후 관찰 소 견상 점막의 비후나 폴립양 변화 등은 없었다. 수술 다음날부 터 통증은 호전되어 수술 전과 같이 시행한 visual analogue scale상 1 점에 해당하였다. 수술 1 개월째 경과 관찰상 상악동 은 크게 개방되어 있는 상태로 특이 이상 소견은 없었다. 수술 6 개월이 지난 현재까지 증상의 재발없이 외래 경과관찰 중이 다(Fig. 4).

\section{고 찰}

부비동이 비정상적으로 팽창된 것은 임상적으로 흔하지 않 으며, 1918년 Benjamins ${ }^{4}$ 이 "Pneumosinus Frontalis"라는 이
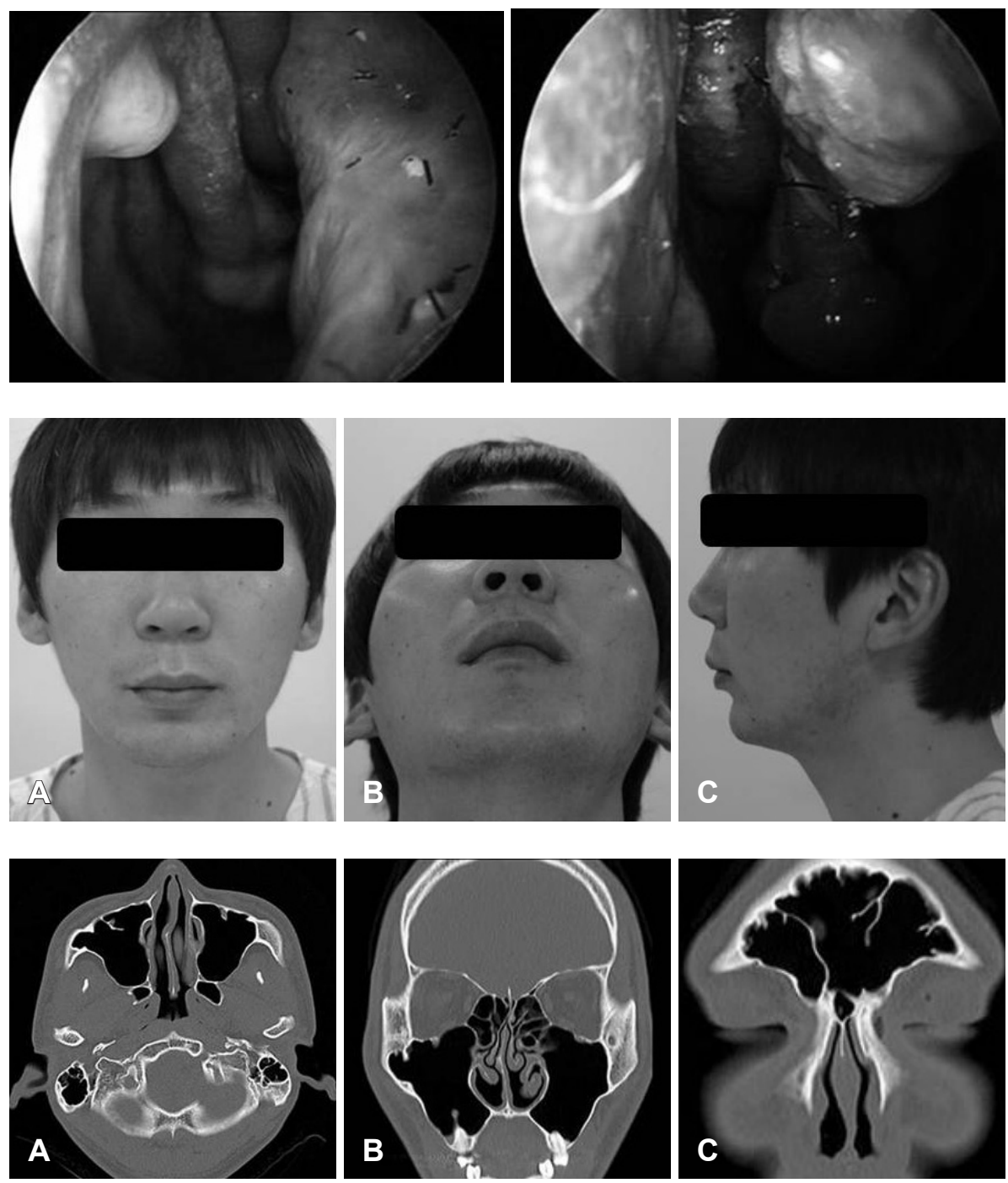

Fig. 2. Preoperative facial photography showing both malar swelling and protruding; frontal $(A)$, basal $(B)$, lateral view (C).

Fig. 3. Preoperative axial computed tomography (CT) showed cystic expansion in the anteromedial wall of the both maxillary sinus (A). Coronal CT image showed thining of the bone of the maxillary sinus (B) and cystic expansion of the frontal sinus (C). 

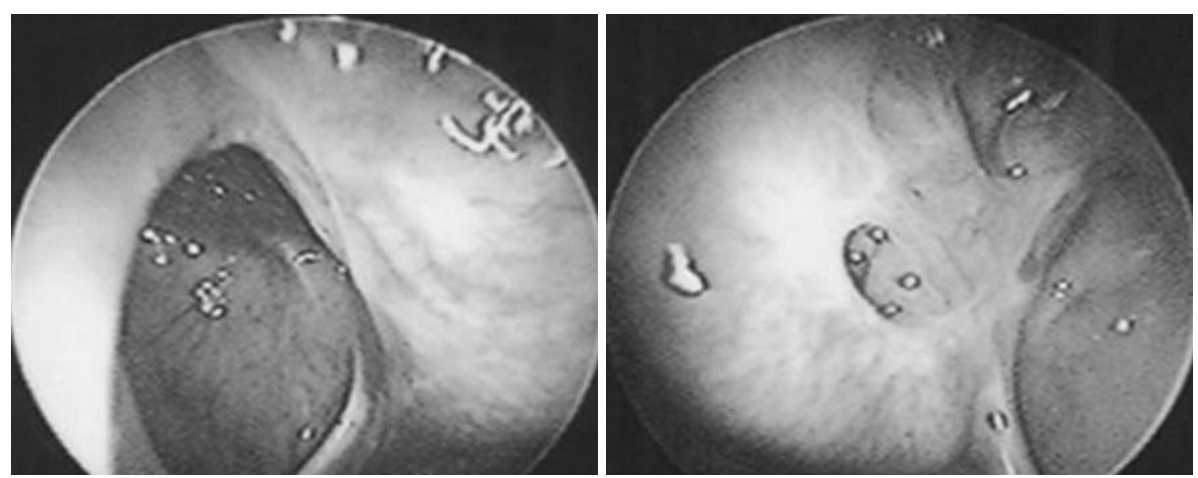

Fig. 4. Endoscopic findings of nasal cavity 1 month after surgery demonstrated enlargement of the natural opening of the maxillary sinus into the middle meatus.

름으로 처음 발표한 이래 air cyst, pneumatocele, pneumocoele, pneumosinus dilatans 등으로 불려왔다. 1987년 Urken 등 ${ }^{5)}$ 은 100 예의 전두동을 조사하고 보고된 예들을 검토하여 비정상적으로 팽창된 부비동을 다음과 같이 1) hyper-pneumatised-sinus, 2) pneumosinus dilatans, 3) pneumocoele의 세 가지 범주로 나누었다. Hyper-pneumatised-sinus는 정상 보다는 팽창되어 있으나 부비동의 정상범주 내에 있으며 증상 을 일으키지 않는 경우, pneumosinus dilatans는 부비동이 정 상범주를 넘어 확장되어 있다. 정상 두께의 부비동 골막을 보 이나 임상적으로 증상을 유발하는 경우, pneumocoele은 정 상범주 이상의 확장과 함께 골막이 얇아졌거나 적어도 부분 적인 결손이 생겼으며 임상적으로 복시, 두통 또는 국소적 압 박 증상을 나타내는 경우이다. 그렇지만 이 모든 경우에서 부 비동내 점막은 항상 정상이어야 한다.)

Peumosinus dilatans의 진단은 일반적으로 영상의학적 검 사로 이루어지며 환자의 외형 변화에 따른 미용적 불만족이나 통증 등의 임상 증상이 동반될 경우 미용적 수술이나 부비동 의 개방을 통한 감압술로 증상의 호전을 경험한 사례가 보고 되었다.

하지만 아직 Peumosinus dilatans의 병인은 잘 알려져 있지 않으며, 세균의 감염이나 점액류의 자연적인 배액, 혹은 선천 적 기형이나 호르몬의 영향, 마지막으로 일방판의 존재 등 5 가 지 정도로 추측된다. ${ }^{6.7)}$ 첫째, 세균감염에 의한 경우 이를 유발 하는 가스를 생성하는 유기체의 존재가 확인되지도 않았을 뿐 만 아니라 정상적인 섬모운동능 및 염증 소견이 없는 수양성 비루를 설명하기 어렵다는 한계점이 있다. 둘째, 갑자기, 자연히 발생하는 콧물로 미루어보아 점액류로부터 공기주머니가 만들 어져 자연배액이 되었을 가능성도 있다. 셋째, 호르몬의 불균 형으로 발생했을 가능성을 제시하는 이론도 있다. 이 기전은 성 호르몬과 성장 호르몬의 불균형으로 인해 조골작용과 파골작 용이 반복적으로 일어나 부비동의 비정상적인 확장을 만들 수 있다고 하지만 아직까지 어떠한 증례에서도 이러한 호르몬의 변화가 보고된 적은 없다. 넷째, 선천기형에 의해 유발될 수 있
다는 설이 있으며, 다섯째, 일방판(one-way valve) 기전은 많 은 저자들로부터 지지받고 있는 기전으로 몇몇 증례에서 크기 가 커진 부비동의 배액 경로에 폴립성의 점막이 존재한다는 사 실이 이를 뒷받침하고 있다. 또한 이 기전은 대기압의 변화나 재 채기시 증상이 심해지는 것을 잘 설명할 수 있다. 이전 증례의 경우에서도 전두골의 전면부 개방술, 상악골의 전면부 개방술 과 경중비도상악동 개방술 등을 통해 증상의 호전을 경험한 경 우 역시 이를 뒷받침 해준다.,6)

본 증례의 경우 증상의 발생이 호흡과 관련되어 흡기에 또 valsalva시 통증이 증가하는 것, 전산화단층촬영상 중비도의 배액경로가 좁다는 것, 다른 약물치료에 반응하지 않는 것, 그 리고 경중비도상악동 개방술 후 환자의 증상이 호전된 점 등 이 일방판 기전과 부합된다 할 수 있다. 이 증례의 의의는 일반 적으로 흔한 전두동이 아닌 상악동에서 발생하였으며 또한 양 측성으로 발생하여 드문 경우라 할 수 있다. 또한 주 증상의 호 소가 안면부위 변형보다는 안면부위 통증인 것이 특징적이며 병변의 발생 기전을 일방판 기전에 기초하여 생각해 경중비도 상악동개방술을 시행하였고 그 결과 증상의 호전을 경험하였 다는 것이다. 부비동의 Pneumosinus dilatans는 흔하지 않으 며 특히 상악동의 Pneumosinus dilatans는 매우 드물게 보고 되고 있다. 따라서 병인이 확실히 밝혀져 있지 않고, 진단과 치 료에 대해 아직까지 정립된 바가 없다. 하지만 본 증례에서처 럼 수년간 약물적 치료와 수술적 치료에도 호전되지 않는 안 면통을 가지고 있는 경우 그 감별진단의 하나로 Pneumosinus dilatans를 생각해 볼 수 있다. 따라서 앞으로도 보다 많은 증 례를 통한 연구가 필요하겠다.

\section{REFERENCES}

1) Adams WM, Jones RI, Chavda SI, Pahor AL, Taifa KT. Pneumosinus dilatans: a discussion of four cases and the possible aetiology. Rhinology 1998;36(1):40-2.

2) Jarvis JF. Pneumocele of the frontal and sphenoidal sinuses. J Laryngol Otol 1974;88(8):785-93.

3) Suryanarayanan R, Abbott G. Pneumosinus dilatans: demonstrated by sinus expansion on serial sinus X-rays with discussion of possible 
aetiology. J Laryngol Otol 2007;121(1):96-9.

4) Benjamins CE. Pneumo-Sinus frontalis dilatans. Acta Otolaryngol 1918;1(1):412-22.

5) Urken ML, Som PM, Lawson W, Edelstein D, Weber AL, Biller HF. Abnormally large frontal sinus. II. Nomenclature, pathology, and symptoms. Laryngoscope 1987;97(5):606-11.
6) Teh BM, Hall C, Chan SW. Pneumosinus dilatans, pneumocoele or air cyst? A case report and literature review. J Laryngol Otol 2012; 126(1):88-93.

7) Karlidağ T, Yalçin S, Kaygusuz I, Demirbağ E. Bilateral pneumosinus dilatans of the maxillary sinuses. Br J Oral Maxillofac Surg 2003; 41(2):122-3. 